\title{
THE CONCEPT OF IMÂM IN SHIA IMAMIYYAH PERSPECTIVE
}

\author{
Hendri Hermawan Adinugraha*, Ahmad Zayadi**, Ahmad Hasan Asy'ari Ulama'i*** \\ *State Islamic Institute of Pekalongan, Pekalongan, Indonesia \\ **, *** Walisongo State Islamic University, Semarang, Indonesia
}

email: *hendri.hermawan@iainpekalongan.ac.id, **ahmadzayadi76@gmail.com, **hasan.a.ulama'i@gmail.com

\section{ABSTRACT}

Khilaffah and imâmah are two terms which are sometimes interpreted equally, that is referring to the meaning of leadership. The term of khilaffah is more widely known to be used to the leadership's term in the Sunni, whereas imâmah is more widely used in the Shiites world of Islam. This article was a literature research that discusses the concept of imamah in the perspective of Shia Imamiyyah. The analysis technique in this study uses content analysis. The purpose of this article is to describe the political developments among the Shiites that culminate in the concept of imâmah as can be witnessed in Iran until now. The results show that wilâyah al-faqîh which was founded by Imam Khomeini after the Islamic Revolution of Iran has been a form of Islamic government led by a fair and capable faqîh in guiding the ummah. The faqîh leadership model still exists in the Islamic Republic of Iran as a form of a mixture of democracy and religious views. So it can be said that wilâyah al-faqîh was a pilot that politics and religion can be unitedin guiding mankind.

\section{ABSTRAK}

Khilâfah dan imâmah adalah dua istilah yang terkadang dimaknai sama, yaitu merujuk pada makna kepemimpinan. Istilah khilafah lebih dikenal luas digunakan untuk istilah kepemimpinan di Sunni, sedangkan istilah imâmah lebih banyak digunakan di dunia Islam Syiah. Artikel ini merupakan penelitian literatur yang membahas tentang konsep imâmah dalam perspektif Syiah Imamiyah. Teknik analisis dalam penelitian ini menggunakan analisis isi. Artikel ini bertujuan untuk mendeskripsikan perkembangan politik di kalangan Syiah yang berujung pada konsep imâmah seperti yang dapat disaksikan hingga saat ini di Iran. Hasilnya menunjukkan bahwa wilâyah al-faqîh yang didirikan oleh Imam Khomeini pasca Revolusi Islam Iran merupakan bentuk pemerintahan Islam yang dipimpin oleh seorang faqîh yang adil dan cakap dalam membimbing umat. Model kepemimpinan faqîh masih ada di Republik Islam Iran sebagai bentuk campuran antara demokrasi dan pandangan agama, sehingga dapat dikatakan bahwa wilâyah al-faqîh merupakan percontohan bahwa politik dan agama dapat dipersatukan dalam membimbing umat manusia.
ARTICLE HISTORY

Received 7 February 2020

Accepted 24 July 2021

\section{KEYWORDS}

Khilâfah; imâmah; Shia; Iran; wilâyah al-faqîh 


\section{Introduction}

Leadership (imâmah) must be present and clear to foster and direct the community demanded in life. Its existence is a necessity. If there is not leadership, the direction of humans away from guidance. If in all in human life always regulated and guided by the sharia, course of leadership of the ummah becomes important thing that must be present and clear.

In contrast to the Sunni views, which gave freedom that the problem of leadership is the public right to be discussed among them, the Shia views, namely the problem of leadership is ushûl al-din, clarity and must be based on texts and intervened by a Prophet or imâm. ${ }^{1}$ In this matter, a person is not permitted to practice his parents, family and counselors, but they must have arguments as in the monotheism and prophethood.

After Prophet Muhammad dead, the Muslims seemed to split into two groups. ${ }^{2}$ The first, the group that argued that the Prophet did not die by determining the caliph afterwards. This group is later known as Ahl al-Sunnah (Sunni). The second, who strongly believes that the successor of the Prophet must be chosen by God through His Prophet, and the Prophet had done it and chosen 'Alî ibn Abû Thâlib, his cousin and son-in-law as his caliph. ${ }^{3}$ This group known as Shia. ${ }^{4}$ Thus it is increasingly clear that the differences that occur in the two major groups of Muslims are whether before the death of the Prophet has appointed and determined someone who replaced his position as the successor to his treatise or not. Shia believed that Muhammad had determined his successor, 'Alî ibn Abû Thâlib, as he had on many occasions, his place and peak at Ghadir Khum. ${ }^{5}$ Sunni Muslims believed that Muhammad did not clearly

\footnotetext{
${ }^{1}$ Muhammad Ridha al-Muzhaffar, Ideologi Syiah Imamiyah (Pekalongan: Al-Muammal, 2003), p. 83.

${ }^{2}$ Nasir Makarim Syirazi, Ma'rifatullah (Jakarta: Abdul Fattah, 1990), p. 97.

${ }^{3}$ There are many narrations in Sunni or Shia literature which include hadiths and narrations relating to
} the event of the appointment of 'Alî ibn Abû Thâlib as the caliph of the Apostle. This event was perpetuated by the events of Ghadir Khumm. That is the event on the $10^{\text {th }}$ of Dzû al- $\underline{\text { Hijjah }} 11 \mathrm{H}$. on the edge of an oasis named Khum where more than 100 thousand muslims come after hajj wadât. On this occasion the Apostle wanted to recall the muslims who had gone through the area and waited for the pilgrims who had not arrived so that all of them would listen to his longest sermon in history. On that occasion the history said: من كنت مولاه فعلي مولاه اللهم وال من والاه وعاد من عاداه. This moment is the most highlighted by Shia Muslims as a foundation of conviction about the determination of the Apostle regarding the caliph (successor) afterwards. This is very reasonable because it is witnessed by the most muslims in historical records so it is not excessive if they say that if this history is not received then it seems that there is no other history that deserves to be accepted. The day and date also in the Shia community were designated as the al-Ghadir feast, namely the day of the appointment of 'Alî ibn Abû Thâlib as caliph, successor of the Prophet.

4 Syâh 'Abd al-'Azîz Ghulâm ㅂakîm al-Dahlawî, Mukhtashar Tuhffah Itsnâ 'Asyarîyyah (Istanbul: Isik Kitabevi, 1981). Not surprisingly, the notion of the term Shia, which was originally interpreted as a follower of a person, became more identical in his journey as a follower of 'Alî ibn Abû Thâlib.

${ }^{5}$ The Shiites claim that what happened was a kind of conspiracy of certain circles, led by 'Umar to seize Alî's rights as the successor to the Prophet's sacred duty. The claim of the existence of the right for 'Alî to replace 83 The Concept of Imâm in Shia Imamiyyah Perspective | Hendri Hermawan Adinugraha, Ahmad Zayadi, Ahmad Hasan Asy'ari Ulama'i 
mention and determine his successors even though they could not deny the events of the Ghadir Khum which were also widely reported among them. ${ }^{6}$ The muslims have the right to choose and determine the caliph again.

This difference will then become a fundamental and prolonged problem between Sunnis and Shiites. Shia argued that the problem of imamah was the central position and the manifestation of precious luthf (grace) for His creatures as a continuation of nubuwwah (prophethood). ${ }^{7}$ It became one of the principles in Shia, namely: faith (tauhîd), prophethood (nubuwwah), justice ('adl), leadership (imâmah), and resurrection day (ma'âd). Whereas imâmah among Sunni Muslims is not rejected, but it is not considered a main principle in religion (more political and social nuances). ${ }^{8}$ The feud between these two major groups occured in hundreds of years by implicating the development of doctrine, theory, political intrigue, natural science and understanding of naqli propositions according to their perspectives. This is politically charged to smooth the groupsinterests rarely.

Research on the concept of leadership in Shia has been carried out by several previous researchers, as a dialog to present the relevance, originalities, and novelty of this research. The several studies related to the context of this research are the views and guidelines for the life of the Shia group are based on the caliph and imâmah. ${ }^{9}$ The doctrine of imâmah was made by the Shia as a great belief, which had implications to the government system. ${ }^{10}$ Wiwin Guanti and Hasiah's research concluded that the emergence of the wilayah alfaqîh system placed the

the Prophet was based on, among other things, the meaning of the Prophet's speech in an event whose nature remained in dispute, namely a kind of public meeting in a place called Ghadir Khum. This event occurred about two months before the Prophet's death, when he was on his way home from the farewell pilgrimage (hajj wadân') asking all his followers to gather at Ghadir Khum before going in various directions. In the big meeting he made a very touching speech (because it signaled that he would soon die). According to the Shiites, the Prophet confirmed the will that 'Alî was his successor. Whereas the Sunnis claimed that as soon as the Prophet died, they consulted in Saqîfah Banî Sa'îdah and agreed to elect and appoint Abû Bakr. Hamid Enayat, Reaksi Politik Sunni-Syi'ah (Bandung: Pustaka, 1988), p. 6-7.

${ }^{6}$ There are different interpretations of the Prophet's wadâ' sermon on this occasion. Sunnis understand that the word مولى is interpreted as a lover, while among Shiites the word is interpreted as a leader. Thus the different meanings will also have an impact on politics.

7 Aboebakar Atjeh, Perbandingan Mazhab-Sji'ah: Rasionalisme dalam Islam (Jakarta: Jajaran Lembaga Penjelidikan Islam Jakarta, 1965), p. 22.

${ }^{8}$ As a Sunni concrete picture accepting all forms of leadership election or determination, either through voting (the case of the election of Abû Bakr), will (as the will of Abû Bakr in the appointment of 'Umar), the election of 'Uthmân (through representatives, syûrâ council), or acclamation ('Alî’s election case).

9 Maafi Husin bin Ali Amran, Muhammad Hilmi Jalil, Zakaria Stapa, Jawiah Dakir, "Analisis Perbandingan Isu Jawatan Khalifah atau Imamah antara Ahlu Sunnah dengan Syi'ah,” Hudan Lin Naas, vol. 1, no. 1 (2020): 36.

${ }^{10}$ Kamaluddin Nurdin Marjuni, “Konsep Kepemimpinan dalam Perspek Teologi Syiah,” Transformasi: Jurnal Kepemimpinan dan Pendidikan Islam, vol. 3, no. 2 (2020): 45.

84 The Concept of Imâm in Shia Imamiyyah Perspective | Hendri Hermawan Adinugraha, Ahmad Zayadi, Ahmad Hasan Asy'ari Ulama’i 
highest legal authority on the walî faqîh or ulama as regulators of all policy in Iran. The wilâyah al-faqih system still uses a democratic system, namely direct elections by the people. ${ }^{11}$ For example, the Shia-Sunni conflict which warmed back after the Arab Spring, it will be clear that the conflict is colored more by political factors. ${ }^{12}$

The purpose of this article is to find out many discourse related to political developments in the Shia which have led to the concept of imâmah happened nowadays. The portrait of Iran as a country which openly carries the Shiite school as a characteristic of its constitution is also interesting evidence to be studied and examined.

\section{The Concept of Imâmah}

Imâmah is an Arabic language rooted in the word imâm. The word imâm itself comes from the word "amma" which means "to follow along". The word imâm means "leader or example that must be followed, or that precedes". People who become leaders must always be up front to emulate as examples and follow along.

In the Quran, the word imâm (singular form) is used 7 times, and the word a'immah (plural forms) is used 5 times with various meaning and intent according to its usage. The classification of the word imâm in the Quran is found in Al-Baqarah (2): 124, Hûd (11): 17, AlHijr (15): 79, Al-Isrâ' (17): 71, Al-Furqân (25): 74, Yâsîn (36): 12, and Al-Aḥqâf (46): 12. Imâm can mean public roads in Yâsîn (36): 12; guidelines in Hûd (11): 7; participate in Al-Furqân (25): 74; and instructions in Al-Ahqâf (46): 12. Likewise in the meaning of leaders, this word refers to many contexts, such as leaders who will be called by God with their people to account for their deeds (Al-Isrâ' (17): 71; leader of unbelievers (Al-Taubah (9): 12); spiritual leaders or Muhammad who were provided with revelations to invite people to do good deeds, establish prayers, perform alms, namely Prophet Ibrâhîm, Ishâq, and Ya'qûb (Al-Anbiyâ' (21): 73); leaders in the broadest sense and are general or in a negative sense (Al-Qashash (28): 5 and 41); and leaders who instruct based on Allah's command (Al-Sajdah (32): 24).

Based on the analysis of the meaning of the word imâm both etymologically, terminologically, and meaning contained in the Quran, it can be argued that the word imâm

11 Wiwin Guanti and Hasiah, “Analisis Konsep Wilayatul Faqih dalam Ketatangeraan Iran,” Jurnal Alwatzikhoebillah: Kajian Islam, Pendidikan, Ekonomi, Humaniora, vol. 7, no. 1 (2021): 11.

12 Ibnu Hajar, "Contemporary Syi'ah-Sunni: From Conflict to Post Arabic Spring Politics and Its Implications in Indonesia," Liwaul Dakwah, vol. 10, no. 1 (2020): 166.

85 The Concept of Imâm in Shia Imamiyyah Perspective | Hendri Hermawan Adinugraha, Ahmad Zayadi, Ahmad Hasan Asy'ari Ulama’i 
based on the Quran, is essentially a title pinned to something either human or also a book that provides guidance of light to good or bad which in every decision be obeyed. ${ }^{13}$ The figure of an imâm is analogous to a kiai (head of a pesantren) for santri as a portrait of a religious-charismatic leader who is treated with respect. ${ }^{14}$

These expressions indicate that the word imâm, which means leader, can be used for several purposes, namely a leader in a negative sense who invites people to immoral acts, leaders in a broad and general sense, and special leaders, namely spiritual leaders. ${ }^{15}$

Imâmah holders are commonly called imâms, as the khilâfah holders are often called caliphs. Al-Râghib al-Ashfahânî (d. 1108) in his famous book al-Mufradât fî Gharîb al-Qur'ân as quoted by Mohammad Reza Modarresee said that, "An imâm is someone who is followed. This can be a person who is followed or kitâb, ${ }^{16}$ books and others." ${ }^{17}$ Whereas the meaning of caliph is someone's successor. These two terms are sometimes used in the same lexical sense in religious texts, but these two terms can also have narrow or broad fields, depending on the scope of their use. Moreover, the real measure proved that there are at least four ordinary expressions and used to refer to this one position, as stated by Muhy al-Dîn ibn Syaraf al-Nawawî (d. 1277) in his expression:

$$
\text { يجوز أن يقال للإمام الخليفة والإمام وأمير المؤمنين , قال الماوردي ويقال أيضا خليفة رسول الله } 18
$$

"Priests may be called the caliph, imâm, amir al-mu'minîn. Mawardi said: "May also be called the caliph of the Prophet."

\section{The Theological Foundation of Shia}

Like other Islamic groups, Shia also has a theological foundation used as a basis for their beliefs. Shia based his beliefs (especially imâmah) on a number of naqli propositions, both those

\footnotetext{
${ }^{13}$ Muhammad Zulkarnain Mubhar, “Konsep Imâm dalam Al-Qur'an: Suatu Kajian Tematik,” Jurnal alMubarak, vol. 4, no. 1 (2019): 29.

${ }^{14}$ Zainuddin Syarif, "Pergeseran Perilaku Politik Kiai dan Santri di Pamekasan Madura," Al-Tahrir, vol. 16, no. 2 (November, 2016): 307.

${ }^{15}$ Ali Syariati, Ummah dan Imamah: Sebuah Konstruksi Sosiologi Pengetahuan dan Interaksi Simbolik dalam Otentisitas dalam Agama (Yogyakarta: Rausyan Fikr, 2009), p. 97.

${ }^{16}$ It is in the humming of the khatm al-qur'ân: واجعله لي إماما و نورا وهدى ورحمة (and make the Quran an imâm for me).

${ }^{17}$ Mohammad Reza Modarresee, Syi'ah dalam Sunnah (Bandung: Citra, 2005), p. 5.

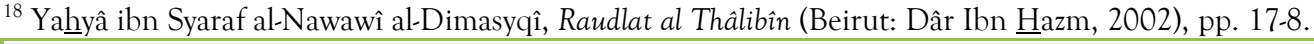


originating from the Quran, hadith or historical events which were not only narrated by their narrators but also by Sunni. ${ }^{19}$

The 'aqli argument that is commonly used as an argument is that after the death of the Prophet there must be a person who continues the struggle and prosecution of the message because of the preaching and dissemination of treatises and efforts to improve society is matter that must exist and that requires the right subject. Imâm is the answer.

In objective literature ${ }^{20}$ the Shia group always made the following verses a basis for their theology of beliefs and teachings. The verses commonly used by Shia Muslims usually start from events related to their first imâm, namely 'Alî ibn Abû Thâlib, among others, namely AlMâ'idah (5): 55:

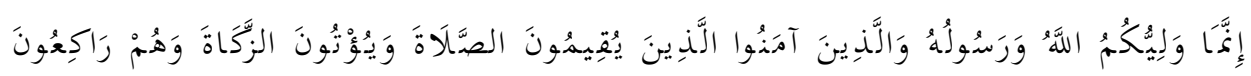

"Your helper is only Allah, His messenger, and those who believe, who establish prayer and perform zakat, as they submit (to Allah)."

This verse is the most reliable basis for the Shiites in legitimizing their beliefs. This verse comes down regarding the arrival of a beggar to the mosque to ask for help, but none of his friends gave him. Then the beggar approached 'Alî who was bowing (in prayer) and he directed his ringed hand towards the beggar to then take it. Not a few scholars from Sunni circles or Shia who recorded this statement interpreted them. In other words, this verse comes down with regard to the alms of 'Alî while praying.

The foundation of the hadith that is often used by Shia is:

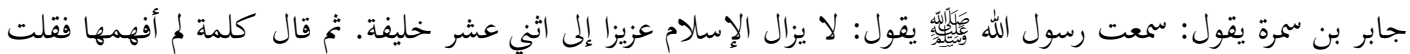

$$
\begin{aligned}
& \text { لأبي: ما قال فقال: كلهم من قريش. } 21
\end{aligned}
$$

"Jâbir ibn Samurah said: "I heard the Messenger of Allah said: 'Islamic religion will remain upright until (passed) twelve caliphs.' Jâbir said: “The Messenger of Allah then said something I did not understand. I also asked my father: "What did he say?" He replied: 'All of them (caliphs) were from Quraysh."”

$$
\text { لا يزال الدين قائما حتى تقوم الساعة أو يكون عليكم اثنا عشر خليفة كلهم من قريش }
$$

\footnotetext{
${ }^{19}$ From this statement until they are willing to bet: that if their argument is rejected, then that means the other party does not believe in the validity and authenticity of their own doctrine and proof. And this is seen as a naive view.

20 That is describing information as it is without being influenced by tendentious attitudes or other motives including a priori attitude and rejection of the beliefs of other groups.

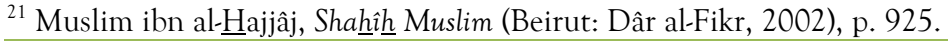

87 The Concept of Imâm in Shia Imamiyyah Perspective | Hendri Hermawan Adinugraha, Ahmad Zayadi, Ahmad Hasan Asy'ari Ulama'i
} 
"This religion will always be upright until the Day of Judgment, or come twelve caliphs, all from the tribe of Quraysh."22

$$
\text { لا يزال هذا الأمر صالحا حتى يكون اثنا عشر أميرا }
$$

"This matter will always be good so that twelve emirs appear." 23

The first hadith that they often made as a basis is hadith of tsaqalain, ${ }^{24}$ and they chose the hadith by using editors that strengthened their beliefs and understandings, moreover the history was also widely spread in various sources by Sunnah experts.

\section{Difference between Khilâfah and Imâmah}

The khilâfah is a distinctive leadership style in Sunni as the holder of the mandate to regulate the interests of the Muslims. In this case, it is more stressed on the surrender of affairs to the public, either directly or representative as indicated by the leadership style in the Islamic world $^{25}$ though in a different way. In this case, the khilâfah is seen as mu'âmalah in which the ownership rights are handed over to the Muslims directly or through their representatives to elect the leadership. This is seen as an ijtihâdî (the thing whose realization is left to the public to carry out the business process or ijtihâd). From the historical record, it is found that the fact that Muslims determine their leadership cannot be separated from 3 types, namely:

1) Selection based on acclamation

The choice of this form in history books (especially from Sunni writers) often made the process of Abû Bakr's choice as caliph (successor of the Apostle) as an example ${ }^{26}$ but there is no agreement to say and argue like that. ${ }^{27}$

${ }^{22}$ A $\underline{h}$ mad ibn $\underline{H}$ anbal, Al-Musnad, vol. 6 (Beirut: Mu'assasah al-Risâlah, 1996), p. 321.

${ }^{23}$ Ibid., p. 323.

${ }^{24}$ That is the hadith which says that the Prophet left two heirlooms that must be held tightly by his people. Even in the hadith the Prophet guaranteed their safety from heresy as long as his people clung to these 2 things. This hadith is quite interesting because there are two different editors (matn al-hadith). One hadith ends with the word كتاب الله وسنة رسوله (which is usually used by Sunni circles), and the second hadith with the editorial staff of the كتاب الله و عترتي أهل بيتي (used by Shiites). Judging from the number of editors the second is very much, except in the Shahîh al-Bukhârî, but it is not as famous as the first editors who only existed in al-Muwaththa' of Mâlik ibn Anas.

${ }^{25}$ At least three types of election of caliphs in history are known which then gain legitimacy from the Sunnis, namely: first, the will system (Umar's election case as Caliph II by Abû Bakr); second, the formation of the syûrâ council (the case of 'Uthmân's caliph after the killing of 'Umar ibn al-Khaththâb) consisting of 6 people namely 'Uthmân, 'Abd al-Raḩmân ibn 'Auf, 'Alî ibn Abû Thâlib, Thalhahah, Zubair and Sa'ad ibn al-Waqqâsh. This unique election succeeded in choosing 'Uthmân as the caliph-III; and third, acclamation (the rise of Abû Bakr as apostle caliph).

${ }^{26}$ Although not all can accept. One of them was the leader of Ansar Sa'ad ibn 'Ubâdah who was also ambitious to become a caliph so that almost the hall of Banî Sa'îdah was contaminated by the blood of the 88 The Concept of Imâm in Shia Imamiyyah Perspective | Hendri Hermawan Adinugraha, Ahmad Zayadi, Ahmad Hasan Asy'ari Ulama’i 
2) Selection based on syûrâ assemblies (assembly of deliberations)

The selection of this form was represented by the history of the election process of 'Uthmân ibn 'Affân, which was preceded by the formation of a syûrâ assembly which 'Umar held to determine candidates who met the criteria according to the provisions of the assembly. And through that process 'Umar's successor was elected. ${ }^{28}$

3) Determination of direct based choice

This form is adopted by democracies whose electoral rights are in the the people. The state only facilitates the elections process.

4) Coronation based on descent

This form applies to the state in the form of monarchy (kingdom). The public cannot possibly refuse or vote, because authority is in the royal family.

5) Election based on a will

This form of election at the beginning of Islamic history occurred at the time of 'Umar's appointment by Abû Bakr (as written in history). And then it also happened in the world of Shia even though with other sentences.

Unlike the Sunnis, the issue of imâmah in Shia was included in the subject of religious affairs (ushêl al-din) whose authority was given by God to the Prophet. Thus, it is not surprising that they argued that it was impossible for the Prophet to leave this treatise without giving up the banner of $d a^{\text {'wah }}$ to the people he chose. They believe that it is very unreasonable if the Prophet does not regulate the problems of the state and its order and even give this matter fully to the people to take care of it. While the smallest business has been given an example to do it. For example: spitting, wearing and removing clothes, entering and exiting toilets, and others. ${ }^{29}$ This is a fundamental and striking difference between Sunnis and Shiites in terms of leadership. But there is a common thread that brings them together, agreeing that whatever the reason and the situation of the leader (imâm, khalifah) must remained.

Muslims who each had the ambition to lead. Until he died Sa'ad did not pledge allegiance to Abû Bakr. And the fact is that the Hashimites as rulers of Mecca (Ka'bah) were not involved in this election at all. They are more preoccupied with taking care of janâzah and funeral of Muhammad.

${ }^{27}$ Abdul Husain al-Amini, Ali ibn Abi Thalib Sang Putra Ka'bah (Jakarta: Al-Huda, 2003), p. 25.

${ }^{28}$ History records 6 people chosen by 'Umar namely 'Abd al-Rahmân ibn 'Auf, Zubair ibn al-'Awwâm, Thalhah ibn 'Ubaid Allâh, 'Alî ibn Abû Thâlib, and 'Utsmân ibn 'Affân. This committee has the duty to discuss choosing a successor to the caliph if he has passed away.

${ }^{29}$ Shia Muslims strongly reject the doctrine which says that state problems are left entirely to people and society, even though this concerns something very urgent, big and serious.

89 The Concept of Imâm in Shia Imamiyyah Perspective | Hendri Hermawan Adinugraha, Ahmad Zayadi, Ahmad Hasan Asy'ari Ulama’i 


\section{Imâmah Position in Shia Perspective}

According to the Shia school, imâmah occupies a very urgent position believed. Imâmah is one of the pillars in the main religion whose existence is something that must be existed as a successor to the treatise of nubuwwah (prophethood). This looks as the luthf (grace) of God to humans to be directed to an orderly and meaningful life order as the goal of creation. ${ }^{30}$ And this affair is meant by prophethood, which is the right of God to choose and determine someone to be an imâm. The appointment was made by an imâm who had been given trust by God before. Therefore, this case in the Shia is believed to be the area of the divine power which does not need to have the beings intervention. And of course, this has nothing to do with inheritance. ${ }^{31}$ So the designation and gesture of the priest is a provision to be obeyed. Shia interpreted this verse from the $\hat{u} l \hat{u}$ al-amr as the priests. They rely on al-Nisâ' (4): 59:

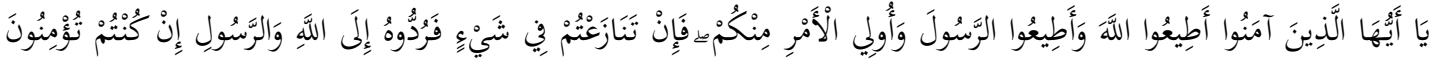

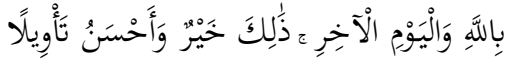

"O ye who believe, obey Allah and obey the Messenger, and $\hat{u} l \hat{u}$ al-amr among you. Then if you have different opinions about something, then return it to Allah (the Quran) and the Messenger (sunnah), if you truly believe in Allah and the day after. That is more important (for you) and better for it."

Shia believed that God's wisdom (al-hikmah al-ilâhiyyah) demanded the need to send apostles to guide humanity. Likewise, about imâmah, namely God's wisdom also requires the need for the presence of a priest after the death of an apostle in order to continue to be able to guide humanity and maintain the purity of the teachings of the Prophet and divine religion from deviations and changes. In addition to explaining the needs of the times and calling on humanity into the path and implementation of the teachings of the Prophet. Without this, the goal of creation, namely perfection and happiness (al-takâmul wa al-sa'âdah) is difficult to be achieved because there is no guidance, so that humanity does not know the direction and teachings of the Prophet to be something in vain. Therefore, Shia believed and held that after the Prophet Muhammad there must be an imâm for every period. ${ }^{32}$ Muslim Shia based this thought and belief on Al-Taubah (9): 119:

${ }^{30}$ Al-Dzârîyyât, verse 56: وما خلقت الجن والإنس إلا ليعبدون (And not I created jinns and humans except only so that they worship Me).

31 Tim Penerbit Al-Huda, Antologi Islam: Sebuah Risalah Tematis dari Keluarga Nabi (Jakarta: Al-Huda, 2007), p. 136.

${ }^{32}$ Nâshir Makârim Syirâzî, I'tiqâdunâ (Kuwait: Mu'assasah 'Ashr al-Dzuhûr, 2009), p. 76.

90 The Concept of Imâm in Shia Imamiyyah Perspective | Hendri Hermawan Adinugraha, Ahmad Zayadi, Ahmad Hasan Asy'ari Ulama'i 


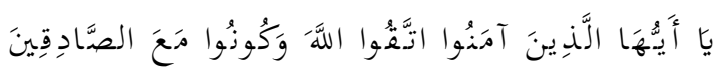

"O ye who believe, fear Allah, and be with the righteous."

The verse according to them does not only apply to the past, but applies to all periods. The call for believers to always be with true people, al-shâdiqin, means to show the existence of infallible imâms that must be followed in every age. This is as mentioned by many Sunni and Shiite commentators on the meaning of this verse. ${ }^{33}$

According to Shia belief, imâmah is not just a political position or formal power, but also a very high spiritual position. ${ }^{34}$ In addition to carrying out government duties, the imâm is also tasked to guide humans in their religious and world affairs. The priest also guides the mind and spirit of the community and maintains the sharia and the teachings of the Prophet so that people do not deviate from the purpose of the sending of the Prophet. This position was originally given by God to Prophet Ibrâhîm after passing the prophetic and treatise phases and was declared to have passed a number of severe examinations. This is contained in Al-Baqarah (2): $124:$

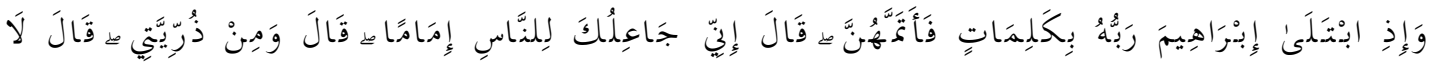

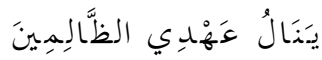

"And (remember), when Ibrâhim tested the Lord with a few sentences (orders and prohibitions), then Ibrâhîm fulfilled it. Allah said: "Truly I will make you a priest for all men." Ibrâhîm said: "(And I beg too) of my descendants." Allah said: "My promise (this) is not concerning the wrongdoers."

\section{'Alî ibn Abû Thâlib: the First Imâm of Shia}

If it is observed from the order of the Shia priests, a glimpse will be found that the names of the priests believed to be revealed are based on lineages. It turns out that this assumption is wrong. It was proved that there were consecutive names of priests, and their status was siblings. Like the case of al- Hasan, which was then continued by al- Husain (his younger brother). Whereas at that time al- Hasan also had a son named al-Qâsim and 'Abd Allâh who would later be martyred in Karbala in the tragedy of $10^{\text {th }}$ Muharam $61 \mathrm{AH}$. That could also be shown to the successor of Muhammad al-Bâqir who was replaced by Ja'far al-Shâdiq-his son, even though

\footnotetext{
${ }^{33}$ Fakhr al-Dîn al-Râzî, after discussing the verse above commented: this verse explains that every person who is jâ'iz al-khatha', can make mistakes, must join and follow people who have been guaranteed the truth. These are those who are referred to by God as true people, al-shâdiqîn. Fakhr al-Dîn al-Râzî, al-Tafsîr al-Kabîr, vol. XVI, p. 221.

${ }^{34}$ Slamet Untung, Melacak Historisitas Syi'ah: Kontroversi Seputar Ahl al-Bait Nabi (Semarang: Pustaka Rizki Putra, 2009), p. 5.

91 The Concept of Imâm in Shia Imamiyyah Perspective | Hendri Hermawan Adinugraha, Ahmad Zayadi, Ahmad Hasan Asy'ari Ulama'i
} 
Muhammad al-Bâqir at that time had a sibling named Zaid. Even so, it can still be concluded that the Shia priests all came from the descendants of "Alî (and Fâthimah)" and especially from the line al-Husain ibn 'Alî. ${ }^{36}$

Priests among Shiites were chosen not based on the choice of the majority votes, nor were they chosen for their representation, but were determined by the previous priests. This distinguishes the caliph election tradition among Sunni Muslims who are selected from one approach namely testamentary, choice of acclamation, choice through a syûrâ assembly or due to inheritance. ${ }^{37}$ As for Shia, an imâm before his death has appointed someone to be his successor. That is sometimes from his immediate descendants or relatives-other relatives. And of course the designation must be based on competence and ability. For more details, we can look at the order of imâm of Shia as follows:

1. 'Alî ibn Abû Thâlib (d. 40 AH)

2. Al-Hasan ibn 'Alî ibn Abû Thâlib (d. $50 \mathrm{AH})$

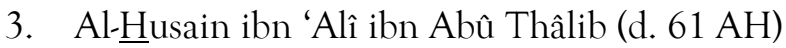

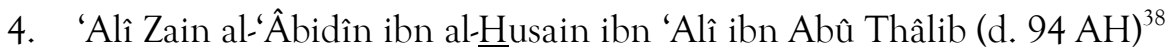

5. Muhammad al-Bâqir ibn 'Alî Zain al-Ấbidîn ibn al-Husain ibn 'Alî ibn Abû Thâlib (d. 113 $\mathrm{AH})^{39}$

6. Ja'far al-Shâdiq ibn Muhammad al-Bâqir ibn 'Alî ibn al- $\underline{\text { Hu} u s a i n ~ i b n ~ ' A l i ̂ ~ i b n ~ A b u ̂ ~ T h a ̂ l i b ~(d . ~}$ $148 \mathrm{AH})$

7. Mûsâ al-Kâdzim ibn Ja'far al-Shâdiq ibn Muhammad al-Bâqir ibn Alî ibn alibn Abû Thâlib (d. 183 AH)

${ }^{35}$ Historical facts note that in the same era 'Alî ibn Abû Thâlib also had a son from his marriage to

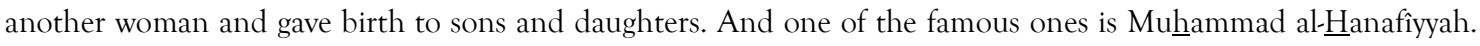
He was always told by his father to advance to the battlefield before both his brothers, al- $\underline{H}$ asan and al- $\underline{H}$ usain.

${ }^{36}$ Muhammad Ridlâ 'Abd al-Amir Anshârî, Su'âl wa Jawâb ma'a al-Nabî wa Ahl Baitih (Kuwait: Mu'assasah 'Ashr al-Dzuhûr, 2009), p. 20.

${ }^{37}$ The latter is a common occurrence in the kingdom or the emirate which oversees millions of people, as happened in Saudi, Kuwait, Bahrain, Qatar and other parts of the Arab. And this is more patterned monarchi (modern kingdom).

${ }^{38}$ Famous for laqab al-Sajjâd (who has many prostrations), the only family man of the Prophet who survived the massacre at the Karbala tragedy on $10^{\text {th }}$ Muharram $61 \mathrm{H}$. He has a collection of prayers known as Shahîfah Sajjâdîyyah. He was born to a Persian princess named Nargis, who was a noble daughter at that time. Perhaps because of that, it is quite understandable that now the Persians (Iran, now) are supporters and loyal followers of this school.

39 By his extreme followers he was made the substitute imâm of his father. This is the embryo of the emergence of the Zaidi Shiites which are now widely spread in Yemen and northern Parsi. And it is suspected that it is very possible that the bearers of Islam to the archipelago were Gujarat merchants who were Muslims who patterned this Shiite school.

92 The Concept of Imâm in Shia Imamiyyah Perspective | Hendri Hermawan Adinugraha, Ahmad Zayadi, Ahmad Hasan Asy'ari Ulama’i 
8. 'Alî al-Ridhâ ibn Mûsâ ibn Ja'far al-Shâdiq ibn Muhammad al-Bâqir ibn 'Alî ibn al-Husain ibn 'Alî ibn Abû Thâlib (d. 202 AH). ${ }^{40}$

9. Muhammad al-Jawwâd ibn 'Alî al-Ridhâ ibn Ja'far al-Shâdiq ibn Muhammad al-Bâqir ibn 'Alî ibn al-Husain ibn 'Alî ibn Abû Thâlib (d. 220 AH)

10. 'Alî al-Hâdî ibn Muhammad al-Jawwâd ibn 'Alî al-Ridhâ ibn Ja'far al-Shâdiq ibn

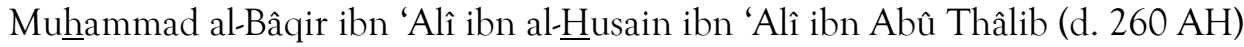

11. Hasan al-'Askarî ibn 'Alî al-Hâdî ibn Muhammad al-Jawwâd ibn 'Alî al-Ridhâ ibn Ja'far al-

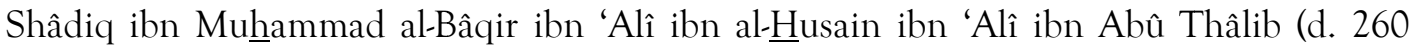
$\mathrm{AH})$

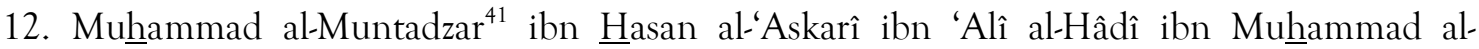
Jawwâd ibn 'Alî al-Ridhâ ibn Ja'far al-Shâdiq ibn Muhammad al-Bâqir ibn 'Alî ibn alHusain ibn 'Alî ibn Abû Thâlib (d. 260 AH) ${ }^{42}$

Based on historical facts, 'Alî ibn Abû Thâlib was named the first imâm of the Shiite school. The question that arises next: "Why must "Alî?" Maybe this question always disturbs the minds of everyone who has not understood by Shia with the intricacies of his teachings. What are the reasons that can be put forward to strengthen the huijah (argument, foothold) why should 'Alî ibn Abû Thâlib be the imâm who became the successor to the Prophet's treatise? Though he is not yet capable enough, ${ }^{43}$ if seen age when the Prophet died. This is where it is more obvious about the benchmarks of a foothold. If the Sunnis emphasize the importance of mental maturity by looking at aspects of age, ${ }^{44}$ so that it becomes a consideration of the feasibility of occupying a leadership position, it does not apply to Shia circles. Shia saw more in accordance with his conviction, that the affairs of imâmah were the area of the divine power which only the

${ }^{40}$ By his followers made a substitute imâm of his father. And this became the embryo of the emergence of the Shia Ismailiyyah which was followed by many Fatimid caliphs.

41 Al-Muntadzar said because according to the belief that the $12^{\text {th }}$ Shia imâm was supernatural (disappearing, hiding from the audience), so that humans were still waiting for his appearance to fill this earth with justice and goodness.

${ }^{42}$ The latter was narrated because he avoided pursuing the authorities so he entered the cave of Samarra in Iraq and then disappeared. And the Shia belief says that this imâm is still awaited his presence, and will be present again before qiyâmah. For khabar this is believed by Muslims as a whole both Sunni or (moreover) Shia. As a result of the belief in these 12 priests, the Shiites who are now the majority proclaim themselves as Shia Itsna 'Asyariyyah or Shia Imamiyyah.

${ }^{43}$ According to the view of the flow that believes that self-maturity and soul are determined by age. When viewed from a relatively younger age compared to other friends such as Abû Bakr, 'Umar, 'Utsmân or others.

${ }^{44}$ It is not uncommon for the Prophet's age to be 40 years old when the beginning of the bi'tsah was made a proposition and pretext for the measurement of a person's maturity and soul so that the delay of 'Alî ibn Abû Thâlib in the fourth row of khulafâ'-râshidûn was acceptable.

93 The Concept of Imâm in Shia Imamiyyah Perspective | Hendri Hermawan Adinugraha, Ahmad Zayadi, Ahmad Hasan Asy'ari Ulama'i 
owner and the minutes of the nubuwwah knew best. It is based on the belief that the message of the prophet will never contradict the giver of the mandate, so that it can be said that the determination of an imâm is not in the mankind power or in the power of Ahl al- $\underline{H}$ all wa al-Aqd (determining the benefit and mutual agreement). ${ }^{45}$ Following this consideration 'Alî ibn Abû Thâlib was crowned priest:

1) 'Alî is the first Muslim

'Alî was the first person to believe in the apostolate of the Prophet after Khadîjah al-Kubrâ binti Khuwailid.

2) 'Alî was the first person to defend and support Islamic da'wah

Although he was not even 15 years old, 'Alî became the only member of the Hashimites who expressed a willingness to fully support the Prophet's preaching. This happened after the Prophet carried out his Lord's command in the verse of indzâr. ${ }^{46}$ In his words Muhammad said to 'Alî after not getting a response of support for his invitation to his relatives before the descent of the verse indzâr:

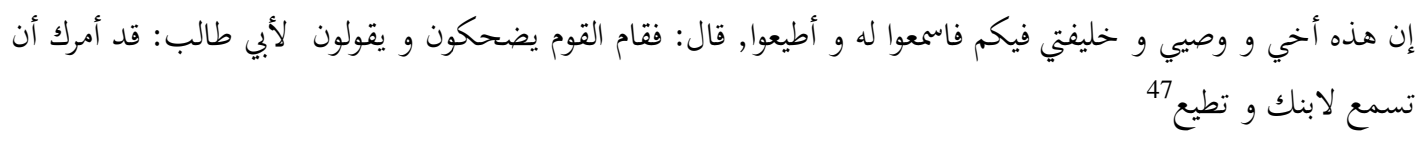

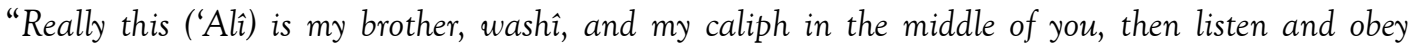

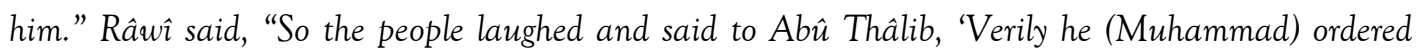
you to listen to your son ('Alî) and obey him."”

3) 'Alî for the Prophet like Aaron for Moses

If Moses is always accompanied by a vizier who always accompanies his preaching, Aaron, then the Prophet is also always accompanied by 'Alî on every occasion so that it is not uncommon (sometimes) to cause jealousy, even by the wives of the Prophet. This familiarity was revealed from the sacred oral of the Prophet who said: "O "Alî, your

${ }^{45}$ Baqir Syarif al-Qurasyi, Untaian Mutiara Keluarga Nabi SAW: Riwayat Hidup Para Imam Suci Ahlul Bait (Jakarta: Lembaga Internasional Ahli Bait, 2007), p. 37.

${ }^{46}$ That is a verse that contains instructions for the Prophet to preach to his family. As stated in the verse: وأنذر عشيرتك الأقربين

${ }^{47}$ Abû Ja'far Muhammad ibn Jarîr al-Thabarî, Târîkh al-Umam wa al-Mulûk, vol. 2 (Cairo: Mathba'ah al Istiqâmah, 1939), pp. 62-3.

94 The Concept of Imâm in Shia Imamiyyah Perspective | Hendri Hermawan Adinugraha, Ahmad Zayadi, Ahmad Hasan Asy'ari Ulama’i 
position on my side is the position of Aaron for Moses. But (remember) there is no Prophet or apostle after me)."48

4) 'Alî is the Medina of Prophet's knowledge

One proof that 'Alî is the Medina of Prophet's knowledge is not at least a historical fact that shows the number of kalâm of "Alî has a high meaning. And the very famous hadith is the Prophet's words: "I am the city of science and 'Alî is the door. Then whoever enters the city, let him go through the door." ${ }^{49}$

5) 'Alî who was crowned the Prophet at Ghadir Khum

This moment for Shia was believed and claimed to be the culmination of the appointment and preaching of the Prophet about his successor, after being hinted on several occasions. That was understandable because it was done by the Prophet after the pilgrimage $\left(18^{\text {th }}\right.$ Dzû al- Hijjah $10 \mathrm{AH}$ ), on the edge of an oasis (Ghadir) named Khum. Therefore this event was very famous with the incident of Ghadir Khum. Among the words of the Prophet which are popular and often used as proof by Shia are:

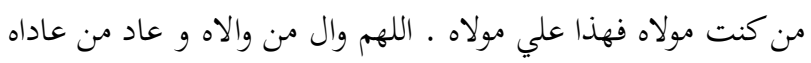

"Whoever acknowledges me as his maula (leader), then this is 'Alî is the leader. O Allah, protect anyone who protects him and enemies whoever is hostile to him."

Shia believe that the priests who are their role models must have conditions, as in the Sunni world that the election of a caliph (leader) cannot be separated from the conditions, even though on the way it is not uncommon for things to happen, then things this also applies to Shiites. The terms of the imâm according to Shia are:

1) 'Ishmah (infallibility, awake from error and sin)

Priests who substitute the Prophet are not just anyone, but must have a number of traits possessed by the Prophet. Therefore, the requirement to become an imâm is not enough for a Quraish, as was believed by a friend at the time, but must also have other conditions,

${ }^{48}$ In the Prophet's history reference, this hadith is famous for the term hadith manzilah. That is the hadith about 'Alî's position on the side of the Prophet. While the editorial of the famous Prophet's words is: يا علي, أنت مني بمنزلة هرون من موسى ولكن لا نبي ولا رسول بعدي

49 Many major problems occurred after the death of the Apostle, namely in the caliphate of the 3 previous caliphs and 'Alî's role became the key to settlement so it was not wrong when 'Umar became caliph once said: لولا علي لهلك عمر (If there is no 'Alî, then woe to 'Umar). These words are spoken more than 40 times in big cases. One books that contain the intelligence of 'Alî is Nahj al-Balâghah, which is full of pearls of wisdom, meaningful advice.

${ }^{50}$ Aḥmad ibn Muhamammad al-Thahâwî, Syarh Musykil al Âtsâr (Beirut: Mu'assasah al-Risâlah, 1994), p. 13. 
namely 'ishmah (the ability to guard against sin even if it is the slightest) and 'ilm (perfect knowledge). ${ }^{51}$ In addition, the Apostle has cooperated with the imâms ('ithrah) with the Quran in hadith of tsaqalain. So as the Quran is protected from mistakes and mistakes, the 'ithrah must also be holy. ${ }^{52}$

2) Be able to guard religion

Perfect obedience, wara' and a combination of zuhd and balanced knowledge will be able to produce brilliant achievements for the existence and preservation of religion in society. ${ }^{53}$

3) To know the most about religion

Beside 'ishmah, science also occupies important positions that support each other. That is, one of them is obtained through perfect knowledge. With his knowledge, a priest knows the religious laws and the consequences of violating the teachings of the religion. With knowledge that is sure ('ilm al-yaqin) and witnesses the consequences of his actions ('ain alyaqin), a priest will always protect himself from immoral acts and sins. Like someone who knows with certain knowledge that hot oil will hurt and destroy his skin, he will not want to dip his hand into a pot filled with hot oil, even though it has never been tried. ${ }^{54}$

4) Defined by the Prophet through the previous priest

Imâm of Shia is only someone appointed and chosen by the Prophet through the previous imâm. This appointment is not based on nasab or kinship considerations, but rather is based on a divine message that is entrusted to the priest because the imâm knows more about the title of the next imâm who will replace it. ${ }^{55}$

\footnotetext{
${ }^{51}$ Syaraf al-Dîn Muhammad Majdzûb al-Tibrîzî, Al Hadâyâ li Syî'ah A'immah al-Hudâ Syarh Ushûl al Kâfî (Qum: Mu'assasah Dâr al-Hadîts al 'Ilmîyyah wa al-Tsaqafîyyah, 1387 H), p. 28.

${ }^{52}$ Muassasah al-Balagh, Mengenal Lebih Dekat Ahlul Bait (Jakarta: Islamic Center Jakarta, 2002), p. 33.

${ }^{53}$ As al-Husain ibn 'Alî ibn Abû Thâlib said famously when he was asked his purpose to Kufa, although he realized the danger of the forces of Ibn Ziyâd (governor of Kufa) must have ambushed him: I did not come out of position, not because of wealth but I went out just to fix things my religion, Muhammad.

${ }^{54}$ Abû Nu'mân (originator of the Hanafiyyah school) when he had studied for two years with Ja'far alShâdiq who was also the teacher of Mâlik ibn Anas, the originator of the Malikiyyah school, once commented: i رأيت من أفقه من جعفر بن مُحَّم

${ }^{55}$ It is unreasonable to accept the priest's coronation only because of the support of a group of fanatical followers, who sometimes support people do not want it. As happened in Shia Zaidiyyah and Ismailiyyah. 


\section{Development of the Shiite Group}

In terms of words, Shia has long been known in the Islamic world. Even in the Quran, at least Shia words are mentioned 7 times. But the word Shia referred to in the Quran still means "group", not meaning the school or theological school as it has been known so far. The terminology of Shia is currently intended to designate followers of 'Alî ibn Abû Thâlib and his descendants, ${ }^{56}$ who are believed to be post-Apostle priests or religious leaders, Muhammad. ${ }^{57}$ The following is the terminology of Shia according to several scholars:

\section{1) Abû al-Fath Muhammad al-Syahrastânî}

"Shia are those who support 'Alî ibn Abû Thâlib and believe in his imâmah and khilâfah based on texts and wills, either express or implied. Besides that they also believe that this imâmah does not come out of his descendants. And if it turns out then it happens because of the tyranny of another party or the taqiyah attitude of the priest himself."

2) Ibn Khaldûn

"Know that Shia in language means friends and followers. According to the terms of the jurists and experts, the Shiites mean the followers of 'Alî and their descendants and masters, all of them who agree that imâmah is not included in the public concern which is entirely left to the view of the people so that they will occupy it. Islamic foundation. It is not permissible for a Prophet to ignore him, and it is not permissible for him to give it to the people but he who determines the priest for them. The imâms are clean of sins, big and small. Indeed, 'Alî is the person who has been determined by the Prophet through the text." ${ }^{\text {}}$

According on the definitions above, it can be understood that the term Shia generally only meant followers or supporters of a general nature, but in its development the meaning was reduced to being followers and supporters of 'Alî ibn Abû Thâlib. ${ }^{59}$ Even specifically the term Shia is enough for anyone who puts 'Alî ibn Abû Thâlib ahead of other friends. ${ }^{60}$

\footnotetext{
${ }^{56}$ al-Dahlawî, Mukhtashar al-Tuhfah, p. 3.

${ }^{57}$ Tim Peneliti Nusantara, Studi Komparartif Buku Mengenal dan Mewaspadai Penyimpangan Syi'ah di Indonesia (Jakarta: Penerbit Titisan, 2014), p. 46.

58 'Abd al-Raḩmân Muhammad ibn Khaldûn, Muqaddimah Ibn Khaldûn, vol.1 (Beirut: Dâr Ihyâ' al-Turâts, 2010), p. 160.

59 Borrowing the use of laqab (title) pinned by Imâm Muslim on his Shahîh in each of his narrations

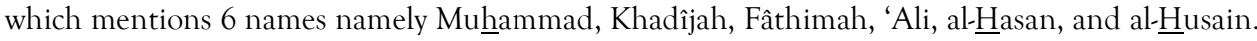

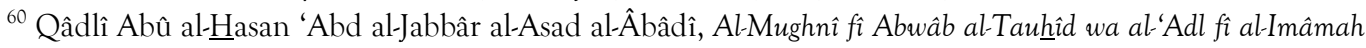

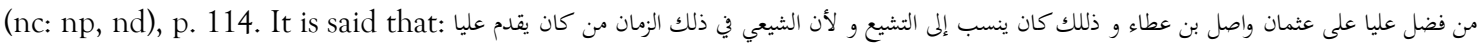
(and the person who prioritizes 'Alî over 'Utsmân is Wâshil bin Athâ', therefore he is called Shia; because the Shia at that time were the people who put 'Alî ahead of 'Utsmân).

97 The Concept of Imâm in Shia Imamiyyah Perspective | Hendri Hermawan Adinugraha, Ahmad Zayadi, Ahmad Hasan Asy'ari Ulama’i
} 
In its development, the Shiite sect was divided into dozens of branches or sects. But among all of them, there are three sects that are large and influential in the Shiite school up to now, namely Zaidiyyah, ${ }^{61}$ Ismailiyyah, ${ }^{62}$ and Itsna 'Asyariyyah also known as Shia Imamiyyah. ${ }^{63}$ The

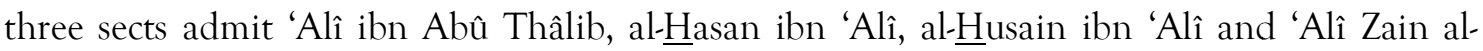
'Âbidîn as their imâm after the death of the Prophet. But after 'Alî Zain al-Ấbidîn, they differed in determining the imam. Some of them chose Zaid ibn 'Alî Zain al-Âbidîn as imâm. This sect became known as the Zaidiyyah. The other group chose 'Alî Zain al-Âbidîn's other son named Muhammad al-Bâqir as their imâm. After al-Bâqir, their imam was Ja'far al-Shâdiq. They again disagreed in determining the priest after Ja'far al-Shâdiq. Some groups appointed Ismâ'îl ibn Ja'far al-Shâdiq. This sect became known as Ismailiyyah. While another group appointed Mûsâ al-Kâdzim. After Mûsâ al-Kâdzim their priests were 'Alî al-Ridlâ, Muhammad

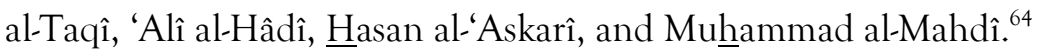

The Shia Imamiyyah school of thought argues that Muhammad al-Mahdî al-Muntazhar experienced two occultations, namely minor occultation which took place in 874-941 AD and major one which lasted until now. During the minor occultation, imâm still demanded the Shia people through their representatives. At that time there were four representatives $(n \hat{a} i b)$ of the imâm who still communicate with Muhammad al-Mahdî. They are 'Utsmân al-Amrî, Abû Ja'far Muhammad ibn 'Utsmân al-Amrî, Abû al-Qâsim Husain ibn Rûh al-Nawbakhtî and Abû alHusain 'Alî ibn Muhammad al-Samarrî. Through these four representatives the imâm communicates with followers of Shia Imamiyyah. After four representatives of the imâm dead, there was a great sacrifice. The Shia Imamiyyah School believes that al-Mahdî did not die, but only God hid from human vision. Only at the end of the age will the imâm of the al-Mahdî

${ }^{61}$ There are many in Yemen, and an example of them is the Houtsi tribe who are now fighting against Saudi aggression in Yemen, after the overthrow of the Sunni Mansour al-Hadi. The Yemeni community adheres to this school due to the role of some followers of 'Alî ibn Abû Thâlib and continued by those who were interested in being loyal and loyal to the leadership of al-Husain ibn 'Alî ibn Abû Thâlib. Among them are Kumail ibn Ziyâd and Mukhtâr al-Tsaqafî before they finally migrated to Kufa, Iraq.

${ }^{62}$ Many spread in India, Pakistan and Bangladesh. And one of the kings who embraced this school was King Jalaluddin Akbar from the line of his mother, queen Hamida. Whereas his father is a Sunni Muslim. King Jalaludin Akbar adheres to the Shia Ismailiyyah with 2 empresses namely Queen Salima and Queen Ruqayyah. The queen Jodha until her death still survives with her belief. From the cultural friction in this era, the Sikhs emerged in India. Namely the religion which is a combination of Hinduism and Islam.

${ }^{63}$ Shia Itsna 'Asyariyyah is said to be due to beliefs held by followers who believe in the leadership of 12 imâms, namely from 'Alî ibn Abû Thâlib to Muhammad ibn Hasan al-Askarî better known as al-Mahdî al Muntadhar. This is the biggest Shia sect whose followers are widely spread in Iran, Iraq, Bahrain, Qatar, Kuwait (North), Saudi (South), Malaysia, and Indonesia. And this is a representation of the Shia authority that still exists.

${ }^{64}$ Moojan Momen, An Introduction to Shi'i Islam (London: Yale University Press, 1985), p. 34. 
emerge to earth to uphold truth, equality, and justice. ${ }^{65}$ The doctrine of the waiting (intidzâr) of al-Mahdî, according to the author, influences many views of the real thoughts and actions of followers of Shia Imamiyyah. Ali Shariati, who is a contemporary Iran scholar, said that waiting is not a concept that requires the followers of Shia to be passive towards the wrongdoers while waiting for the imâm to release them. According to him, Shia followers must be active in opposing in various ways every form of arbitrariness and tyranny of the ruler. Intidzâr means a statement of disagreement and rejection of the situation of today's oppressed Muslims. Intidzâr means rejecting crime, oppression, injustice, and abuse. Intidzâr is also a constant struggle for freedom and justice. ${ }^{66}$

It was during this time of negligence that the leadership relay was held by the jurisprudence of Shia Imamiyyah. This is what is meant by wilayah al-faqîh or power held by the faqîh. The concept of wilâyah al-faqîh popularized by Imam Khomeni was the milestone for the success of the Iran Islamic Revolution in 1979 so that the government of the Islamic Republic of Iran was formed.

\section{Iran: Representation of the Shiite Developed Countries in the World}

Islamic Republic of Iran (Jumhuri ye Islame ye Iran) is a country that has gone through a long history. In the past (starting from the 6th century BC), Iran (formerly known as the Persian name) was one of the largest empires in the world besides Rome. During that time the Iran managed to build its civilization to be recognized as one of the most civilized nations in history. ${ }^{67}$ Since many years ago, Iran become a nation that was taken into the political contestant and world civilization. The dynasties reformation ruled in Iran for about 25 centuries, but still did not eliminate the influence of the Iran in terms of culture and civilization. This ultimately affected the high nationalist spirit and nationalism of Iran. ${ }^{68}$

In the map of the Islamic world, Iran is a representation of the Persian region with a majority population embracing Shia Imamiyyah. Shia Imamiyyah got a special place as the

\footnotetext{
${ }^{65}$ Momen, An Introduction, pp. 163-5.

${ }^{66}$ Ali Syari'ati, “Awaiting the Religion of Ptotest," in John L. Esposito and John D. Donohue, Islam in Transition: Muslim Perspective (Oxford: Oxford University Press, 1982), p. 350.

${ }^{67}$ Encyclopedia of Iranica, vol. IV (California: Columbia University Pres, 1989), pp. 98-9.

${ }^{68}$ Abd. Kadir, “Syi'ah dan Politik: Studi Republik Islam Iran,” Jurnal Politik Profetik, vol. 5, no. 1 ( 2015): 1-15.

99 The Concept of Imâm in Shia Imamiyyah Perspective | Hendri Hermawan Adinugraha, Ahmad Zayadi, Ahmad Hasan Asy'ari Ulama’i
} 
official state school since the establishment of the Shafawi dynasty (in 1501). ${ }^{69}$ Since then, the Shia Imamiyyah teachings have had a dominant influence on the social structure and life of the Iran people. Imami Shiite schools increasingly show their influence on Iran, especially after the advent of the Iran Islamic Revolution in 1979 led by Ayatollah Khomeini and succeeded in overthrowing the Pahlavi dynasty and replacing it with the Islamic Republic and the wilâyah alfaqîh system as a system of government adopted from the imâmah system in Imami Shiite beliefs. Since the 1979 Islamic revolution led by Ayatollah Khomeini, Iran has carved out a new history in its political history, becoming the Islamic Republic with the wilâah al-faqîh system as its system of government. ${ }^{70}$

The roles of a capable faqih as a priest's representative are: 1) Making a fatwâ; with regard to guidance in government and religious duties, it is inevitable for those who lack sufficient knowledge in Islamic law and the sharia system to refer to the opinions of a faqîh. Fuqahâ' who made a legal fatwâ known as marja' al-taqlid, and followed or obeyed their opinions was called taqlid. Even though fiqh experts must have certain qualities to hold this role no explicit permission is required from an imâm; 2) Judging (al-qadlâ'); legally it is recognized that a fair faqîh is able to mediate disputes and decide legal matters. Immigrants believe that this function belongs to the field of priestly authority. Therefore only those who get the permission of the priest may hold this role; and 3) Supervising hisbîyyah affairs; Imamiyyah jurisprudents

${ }^{69}$ During this Shafawi dynasty the laws were really applied normatively, besides that the discourse of thought and sufism ('irfân) which had a Shia pattern was quite rapidly developing and at this time many great Shiite thinkers such as Mir Damad, Mulla Shadra, Mulla were born Hadi Shabzavari, and others. This Shafawi government policy really made Shia's teachings as teachings that had a broad influence on the social life of the Iranian people and had an influence until later. Ibid.

${ }^{70}$ Wali and wilayah words have the same root. From its main meaning, which is close to someone or with something, it is drawn to general meanings such as getting assignments, governing, and exercising authority. In the terminology of Islamic law, the term wilâyah has several uses including as followers of: 1) Qilâyah al-Qarabâ'; This type of authority wilayat is given to a father or grandfather from the father line for children or those who are mentally dependent (even to adulthood). The authority to act as guardian is based on the relationship of kinship; 2) Wilâyah al-Qadlâ'; According to Imami Islamic jurisprudents, priests originally had the sole authority to try people based on law and divine revelation. But at this time, a capable faqîh can take this responsibility with the priest's permission; 3) Wilâah al-Hâkim; In this case the authority is given to the administrator of an ordinary judge to oversee the interests of someone who is unable to carry out his own affairs, such as a person who is weak in his mind or a person who is mentally ill. For anyone who does not have a guardian, the jurist says, it is the judge who will be the guardian of those who do not have a guardian; 4) Wilâyah Muthlaqah (absolute authority); Imami jurists believe that the Prophet and the Imams had divine authority over the people; 5) Wilâah al-Usuba; According to Sunni jurisprudence experts this authority is associated with inheritance rights, which establishes the classification of heirs. Such categories of territory cannot be accepted by Imamiyyah jurisprudents. According to the doctrine of Imamiyyah, absolute authority remains with an obscure priest. Therefore to exercise authority, every faqîh that is just and capable requires authority from the priest, who in turn is appointed by God as the absolute owner of authority and guardianship. Ahmed Vaezi, Agama Politik: Nalar Politik Syiah (Jakarta: Citra, 2006), pp. 84-7.

100 The Concept of Imâm in Shia Imamiyyah Perspective | Hendri Hermawan Adinugraha, Ahmad Zayadi, Ahmad Hasan Asy'ari Ulama’i 
expanded this role into a series of functions that required official trustees to oversee them; these affairs are known as al-umûr al-hisbiyyah, and include gifts on the basis of religion, inheritance, and funerals. These three functions are a fraction of the authority of the priest in the history of Shia Imamiyyah, most of which are limited to these three central roles. However, the authority and religious duties of a priest as a guardian cover much broader than the three functions above. Those who believe in universal territory (wilâyah 'âmmah) still hold that the role of faqih is not limited to only a small portion of religious duties, but even he has the same authority as the imâm. He has the right and duty to lead the Shia community and holds full functions and responsibilities like a priest. In addition to handling the wilâyh of al-qadlâ' and al-hisbah, priests also have the right to carry out government, legal and economic duties. ${ }^{71}$

In terms of politics, Iran displays a distinctive style in the thinking and political system of Islam with the leadership of the State held by the ulama (mullah). The wilâyah al-faqîh system is a political ijtihâd of Ayatollah Khomeini based on the doctrine of imâmah in Shia Imamiyyah. The success of the 1979 Islamic revolution was enough to influence the rise of political awareness and self-confidence of Muslim nations in the world. A nation with a dynastic government that lasted for 25 centuries which was supported by the power of the United States and Britain was finally able to fall with the power of the masses spearheaded by the Mullahs. As a result, Iran later became the first Shia state to base the form and system of its country's government on the political concept of Shia Imamiyyah. The success of the Iran state today is one of the nations that is considered by the West (especially the United States and Britain) and its correlation with Iran as the country that made Shia Imamiyyah the official state school. During the early days of the revolution, Iran experienced quite difficult times, especially with the events of the Iran-Iraq war for 8 years (1980-1988). This war drained energy and caused many losses and casualties to Iran. But the Iran-Iraq war was not enough to shake the existence of the newly formed Islamic Republic of Iran. Iran gradually began to build its strength on every important line in the life of the nation and state between science and the military. Until now, Iran has become one of the nations or Muslim countries whose existence is quite respected by the international community including the United States, Britain and its allies Israel. $^{72}$

${ }^{71}$ Ibid., p. 87-90.

${ }^{72}$ Kadir, "Syi'ah dan Politik", p. 5. 
Nevertheless, the Shiite school showed its influence by being the basis of the ideology and instruments of Iran state's social and political system. The wilâyah al-faqîh system is the political system of the Iran state in the form of the Islamic Republic. The highest power is in the hands of scholars as a spiritual leader called rahbar. The governance structure of wilâah al-faqîh is centered in the hands of the Central Government but in its implementation is in the form of a triaspolitica, ${ }^{73}$ consisting of 3 legislative bodies (parliament, expert council, and expert assembly), executive power in the hands of the president, ${ }^{74}$ and judicial power in the hands of the supreme court or the supreme council of national justice. In addition there is a revolutionary council, a political and economic council of the revolution, and a religious leader who functions as a local administrator.

Until now, according to Mohammad Javad Zarif (Iran Foreign Minister) the strength of the system of the Islamic Republic rests on the people, he also considers that Iran's security, economy, technology, and defense strength come from internal factors. ${ }^{75}$ The Islamic Republic of Iran has resisted all pressure, sanctions, war, and hostilities for 38 years and it emerged as a winner on all fronts, Iran was also able to achieve progress in various fields ranging from the nuclear industry to the latest economy and technology.

The Zarif statement is also proven by a report from the Science-Metrix study which states that scientific progress in Iran is eleven times faster than other countries in the world. Even the technological developments in Iran in 2017 are very fast even surpassing China which is recognized by the world as brilliant in science. Despite more than 30 years of Western embargo, Iran has taken great strides in various sectors, including the space, nuclear, medical,

${ }^{73}$ In the $20^{\text {th }}$ century of justice, where economic and social life has developed to be so complex, the concept of "trias politica" is deemed inadequate. With the development of the concept of a "welfare state" in which the government is responsible for the welfare of all the people and therefore has to carry out overall economic and social development planning, the state function is far more complex than the three kinds offered by Montesquieu. Therefore, various views emerged such as liberal democracy, constitutional, violet, Pancasila, and also the concept of wilâyah al-faqîh. Each of these democracies considers the ideal. Mariam Budiardjo, Dasar-dasar Ilmu Politik (Jakarta: Gramedia, 1993), p. 152.

${ }^{74}$ For executive power, the highest power of the state in the wilâyah al-faqih system is the president who is still under the power line of the rahbar. Regarding the conditions of a president, the Iranian people must be reviewed in terms of origin and nationality, obedience to worship, and following the state's official school of thought. President's loyalty to Shia as the official state school is also affirmed by his oath of office; ... I will protect this country's official school of thought ... ". The Great Ambassador of the Islamic Republic of Iran, Konstitusi Republik Islam Iran 1979 (Jakarta: Kedutaan Besar Republik Islam Iran, 2000), p. 7.

${ }^{75} \mathrm{He}$ revealed this at the event commemorating the martyrs of the Foreign Ministry in Tehran. Anonymous, "Menlu Zarif: Kekuatan dan Kemajuan Iran Berasal dari Dalam," Parstoday, February, 26, 2017, http://parstoday.com/id/news/iran-i33512-menlu_zarif_kekuatan_dan_kemajuan_iran_berasal_dari_dalam, accessed on 7th February 2020. 
cell research, and cloning sectors. Iran successfully launched a satellite named Kavoshgar 3 into space. The satellite carried various living organisms such as mice, two turtles and worms for research purposes. Another Iran progress is that Iran became the first country in the Middle East to be able to breed transgenic livestock, such as sheep and goats. Iran is also noted as one of the few countries that has succeeded in developing technology and tools to clone livestock that can be used for medical research purposes and to produce human antibody substances to ward off disease. The lamb named Royana and two cows named Bonyana and Tamina are the first cloned animals in Iran. ${ }^{76}$

\section{Conclusion}

Based on the explanation above, it can be concluded that the caliphate and imâmah both are two terms which are sometimes interpreted equal, namely referring to the meaning of leadership. The term khilaffah is more commonly used to term leadership in the world of Sunni, while imâmah is more widely used in the Shia. The caliph was elected by the people or Ahl alHall wa al-Aqd, and this was a multi interpretation. The imâm is a decree of God which is entrusted to the Prophet to determine his successor. And the next determination is appointed by the previous imâm according to the will they received.

Another interesting coursecan be taken from the political style of imâmah is that the state leader at the same time is become a religious one. In the Shia Imamiyyah perspective, religion and politics cannot be separated as exemplified by the Prophet Muhammad in Islamic government in Medina. The Prophet gave the relay of Islamic imâmah to 'Alî and his descendants. A leader should be obedient, clean and reliable in his behavior and morals. According to Shia, a state leader who is also a marja' (a place of reference for religious affairs), will further strengthen the course of state development without any worries being hampered by issues that develop in the community. A leader who is intelligent but also clever and smart is able to bring direction to progress and prosperity and this can be seen in the progress of the State of the Islamic Republic of Iran. Imâmah was very important in the Shia Imamiyyah belief so that they made it as ushûl al-mazhab. Wilâyah al-faqîh which was initiated by Imâm Khomeini after the Islamic Revolution of Iran is a form of Islamic government led by a just faqîh and

76 Science-Metrix, "Secular Movements in Knowledge Creation," Science-Metrix, http://www.sciencemetrix.com/sites/default/files/science-metrix/publications/30years-paper.pdf, accessed on $7^{\text {th }}$ February 2020.

103 The Concept of Imâm in Shia Imamiyyah Perspective | Hendri Hermawan Adinugraha, Ahmad Zayadi, Ahmad Hasan Asy'ari Ulama’i 
capable in guiding the ummah. This faqîh leadership model which still exists up to nowadays in the Islamic Republic of Iran is a form of a combination of democracy and religious views. So, it can be said that this wilâyah al-faqîh is a demonstration that politics and religion can be combined in guiding humanity in general and Muslims in particular.

\section{References}

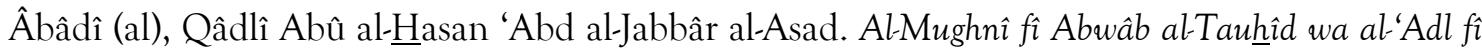
al-Imâmah. nc: np, nd.

Amini (al), Abdul Husain. Ali ibn Abi Thalib Sang Putra Ka'bah. Jakarta: Al-Huda, 2003.

Anonymous. "Menlu Zarif: Kekuatan dan Kemajuan Iran Berasal dari Dalam.” Parstoday, February, 26, 2017, http://parstoday.com/id/news/iran-i33512menlu_zarif_kekuatan_dan_kemajuan_iran_berasal_dari_dalam, accessed on $7^{\text {th }}$ February 2020 .

Anshârî, Muhammad Ridlâ 'Abd al-Amir. Su'âl wa Jawâb ma'a al-Nabî wa Ahl Baitih. Kuwait: Mu'assasah 'Ashr al-Dzuhûr, 2009.

Atjeh, Aboebakar. Perbandingan Mazhab-Sji'ah: Rasionalisme dalam Islam. Jakarta: Jajaran Lembaga Penjelidikan Islam Jakarta, 1965.

Budiardjo, Mariam. Dasar-dasar Ilmu Politik. Jakarta: Gramedia, 1993.

Dahlawî (al), Syâh 'Abd al-Azîz Ghulâm Hakîm. Mukhtashar al-Tuhfah al-Itsnâ 'Asyarîyyah. Istanbul: Isik Kitabevi, 1981.

Dimasyqî (al), Yahyâ ibn Syaraf al-Nawawî. Raudlat al Thâlibîn. Beirut: Dâr Ibn Hazm, 2002.

Enayat, Hamid. Reaksi Politik Sunni-Syi'ah. Bandung: Pustaka, 1988.

Encyclopedia of Iranica, vol. IV. California: Columbia University Pres, 1989.

Esposito, John L. and John D. Donohue. Islam in Transition: Muslim Perspective. Oxford: Oxford University Press, 1982.

Guanti, Wiwin and Hasiah. "Analisis Konsep Wilayatul Faqih dalam Ketatangeraan Iran." Jurnal Alwatzikhoebillah: Kajian Islam, Pendidikan, Ekonomi, Humaniora, 7 (1): 11.

Hajar, Ibnu. "Contemporary Syi'ah-Sunni: From Conflict to Post Arabic Spring Politics and Its Implications in Indonesia.” Liwaul Dakwah, 10 (1): 166.

Hajjâj (al), Muslim ibn. Shahîh Muslim. Beirut: Dâr al-Fikr, 2002.

Hanbal, Ahmad ibn. Al-Musnad ,vol. 6. Beirut: Mu'assasah al-Risalah, 1996.

Husin, Maafi bin Ali Amran, Muhammad Hilmi Jalil, Zakaria Stapa, Jawiah Dakir. "Analisis Perbandingan Isu Jawatan Khalifah atau Imamah antara Ahlu Sunnah dengan Syi'ah." Hudan Lin Naas, 1 (1): 36.

Kadir, Abd. "Syi'ah dan Politik: Studi Republik Islam Iran.” Jurnal Politik Profetik, 5 (1): 1-15. 
Khaldûn, 'Abd al-Rahmân Muhammad ibn. Muqaddimah Ibn Khaldûn, vol.1. Beirut: Dâr Ihyâ' al-Turâts, 2010.

Marjuni, Kamaluddin Nurdin. "Konsep Kepemimpinan dalam Perspek Teologi Syiah." Transformasi: Jurnal Kepemimpinan dan Pendidikan Islam, 3 (2): 45.

Modarresee, Mohammad Reza. Syi'ah dalam Sunnah. Bandung: Citra, 2005.

Momen, Moojan. An Introduction to Shi'i Islam. London: Yale University Press, 1985.

Muassasah al-Balagh. Mengenal Lebih Dekat Ahlul Bait. Jakarta: Islamic Center Jakarta, 2002.

Mubhar, Muhammad Zulkarnain. "Konsep Imâm dalam Al-Qur'an: Suatu Kajian Tematik." Jurnal al-Mubarak, 4 (1): 29.

Muzhaffar (al), Muhammad Ridha. Ideologi Syiah Imamiyah. Pekalongan: Al-Muammal, 2003.

Qurasyi (al), Baqir Syarif. Untaian Mutiara Keluarga Nabi SAW: Riwayat Hidup Para Imam Suci Ahlul Bait. Jakarta: Lembaga Internasional Ahli Bait, 2007.

Râzî (al), Fakhr al-Dîn. Al-Tafsîr al-Kabîr, vol. XVI.

Science-Metrix. "Secular Movements in Knowledge Creation." Science-Metrix, http://www.science-metrix.com/sites/default/files/science-metrix/publications/30yearspaper.pdf, accessed on $7^{\text {th }}$ February 2020.

Syariati, Ali. Ummah dan Imamah: Sebuah Konstruksi Sosiologi Pengetahuan dan Interaksi Simbolik dalam Otentisitas dalam Agama. Yogyakarta: Rausyan Fikr, 2009.

Syarif, Zainuddin. "Pergeseran Perilaku Politik Kiai dan Santri di Pamekasan Madura." AlTahrir, 16 (2): 307.

Syirazi, Nasir Makarim. Ma'rifatullah. Jakarta: Abdul Fattah, 1990.

Syirazi, Nâshir Makârim. I'tiqâdunâ. Kuwait: Mu'assasah 'Ashr al-Dzuhûr, 2009.

Thabarî (al), Abû Ja'far Muhammad ibn Jarîr. Târîkh al Umam wa al Mulûk, vol. 2. Cairo: Mathba'ah al Istiqâmah, 1939.

Thahâwî̀ (al), Aḥmad ibn Muhammad. Syarh Musykil al Âtsâr. Beirut: Mu'assasah al-Risâlah, 1994.

The Great Ambassador of the Islamic Republic of Iran. Konstitusi Republik Islam Iran 1979. Jakarta: Kedutaan Besar Republik Islam Iran, 2000.

Tibrîzî (al), Syaraf al-Dîn Muhammad Majdzûb. Al Hadâyâ li Syî̀ah A'immah al-Hudâ Syarh Ushûl al Kâfî. Qum: Mu'assasah Dâr al-Hadîts al 'Ilmîyyah wa al-Tsaqafîyyah, 1387 H.

Tim Penerbit Al-Huda. Antologi Islam: Sebuah Risalah Tematis dari Keluarga Nabi. Jakarta: AlHuda, 2007.

Untung, Slamet. Melacak Historisitas Syi'ah: Kontroversi Seputar Ahl al-Bait Nabi. Semarang: Pustaka Rizki Putra, 2009.

Tim Peneliti Nusantara. Studi Komparartif Buku Mengenal dan Mewaspadai Penyimpangan Syi'ah di Indonesia. Jakarta: Penerbit Titisan, 2014.

Vaezi, Ahmed. Agama Politik: Nalar Politik Syiah. Jakarta: Citra, 2006. 